\title{
Dividend Policy Responses to Deregulation in the Electric Utility Industry
}

\author{
Julia D'Souza ${ }^{1}$, John Jacob ${ }^{2}$ \& Veronda F. Willis ${ }^{3}$ \\ ${ }^{1}$ Johnson Graduate School of Management, Cornell University, Ithaca, NY 14853, USA \\ ${ }^{2}$ Posthumous \\ ${ }^{3}$ College of Business and Technology, The University of Texas at Tyler, 3900 University Boulevard, Tyler, TX \\ 75799, USA
}

Correspondence: Julia D’Souza, Associate Professor of Accounting, 368 Sage Hall, Cornell University, Ithaca, NY 14853, USA. E-mail: jd48@cornell.edu

Received: January 14, 2015

Accepted: February 16, $2015 \quad$ Online Published: February 19, 2015

doi:10.5430/ijba.v6n2p1

URL: http://dx.doi.org/10.5430/ijba.v6n2p1

\begin{abstract}
This paper investigates changes in electric utilities' dividend policies following the onset of deregulation. Consistent with the theory of dividend clienteles, we find that utilities continue to pay high dividends after the onset of deregulation. Under a regulated regime, we find no systematic pattern of associations between dividend changes and abnormal stock returns or future earnings changes. Post-deregulation, however, we find that, consistent with prior research on unregulated firms, dividend increases (decreases) are viewed by the market as good (bad) news. When we examine earnings following changes in dividends, we do not find evidence in favor of the dividend signaling theory.
\end{abstract}

Keywords: electric utilities, deregulation, dividend policy

\section{Introduction}

The Energy Policy Act of 1992 deregulated the wholesale sector of the electric utility industry and signaled that the industry would soon undergo retail sector deregulation. However, deregulation has posed a series of challenges to utilities. In the regulated regime, utilities were guaranteed a fair rate of return on their investment in return for providing reliable power to customers. Limited investment opportunities and low business risk made it optimal for utilities to pay out most of their earnings as dividends. Utilities were characterized by regular and high dividend payments and were sometimes referred to as "widows and orphans stocks" because their regular dividends were ideal for investors who required a fixed income.

As utilities underwent deregulation, their business risk has increased as they are no longer assured a fair rate of return and have to operate in a competitive marketplace (Johnson et al, 1998). Utilities' investment opportunities have increased as they are now allowed to diversify into other industries. Thus, it is possible that the high payout dividend policy is no longer optimal. However, if electric utilities wish to retain their existing investor clientele, they might persist with their high dividend payout policies despite the changed business environment.

In this paper, we examine the effect of deregulation in the electric utility industry on the dividend policies of investor-owned utilities. There are competing theories to explain firms' dividend policies but definitive answers are hard to find in prior research. The utility industry transition from a regulated to a deregulated environment is an interesting setting to examine dividend policy issues. In a regulated environment, many of the traditional arguments used to explain dividend policy do not apply. As firms move to a deregulated environment, they are, for the first time, subject to the same competitive forces that affect other firms. The changes they make to their dividend policies and the market's reactions to these changes are informative about dividend policy in all firms.

We examine changes in the level of electric utility dividends following the onset of deregulation. Controlling for other factors that could affect dividends, we find that dividends per share have remained relatively stable while dividend yield has decreased and the dividend payout ratio has increased. This is consistent with electric utilities maintaining their high dividends, despite lower profitability after deregulation. Next we investigate the stock market reaction to news of electric utilities dividend changes. In the regulated period, we find little evidence of associations 
between dividend changes and abnormal stock returns around the announcement dates of these changes. After the onset of deregulation, we do find a pattern of association similar to that of firms in unregulated industries. This finding is consistent with both the signaling and the free cash flow theory for dividends. To distinguish between these two theories, we examine the association between abnormal returns around dividend announcements and proxies for firms' investment opportunities. We also study the relation between dividend changes and future earnings changes. Some of our results are consistent with the free cash flow theory for dividends but our results are generally not consistent with the signaling theory.

\section{Prior Research}

There has been considerable prior research on dividend policy starting with Lintner (1956) (Note 1). However, the evidence from prior research is mixed. First, relying on asymmetric information between managers and investors, the dividend signaling theory (e.g., Bhattacharya, 1979, John and Williams, 1985, Miller and Rock, 1985), suggests that managers who foresee a bright future pay high dividends as a credible signal to the market of their private beliefs. Several papers have attempted to test this theory empirically with mixed results. Watts (1973) finds weak evidence of a relationship between current dividends and future earnings. John and Lang (1991) examine the direction of insider trading around dividend changes and document evidence in favor of this theory. Healy and Palepu (1988) provide evidence that firms that initiate dividends are supportive of the dividend signaling theory but those that omit dividends are not. DeAngelo et al. (1996) analyze firms that had an earnings decline after nine or more consecutive years of growth and find no support for the signaling hypothesis. Benartzi et al. (1997) and Grullon et al. (2005) examine earnings changes following dividend changes, and find that dividend changes do not generally predict earnings changes in the same direction. However, results in Nissim and Ziv (2001) are supportive of the dividend signaling theory.

Another theory is based on agency conflicts between shareholders and managers and/or debt holders. The free cash flow hypothesis (Jensen, 1986) suggests that, in the absence of monitoring mechanisms, managers of firms with free cash flows will invest these cash flows in negative net present value (NPV) projects. Dividend payments could be viewed as reducing managers' ability to make these negative NPV investments and therefore dividend increases may be interpreted as good news. Lang and Litzenberger (1989) examine stock price reactions to dividend changes by firms with differing investment opportunities, proxied for by Tobin's Q, and report evidence consistent with this theory. Jensen et al. (1992) and Agrawal and Jayaraman (1994) find a negative relationship between leverage and dividend payout, consistent with the free cash flow theory. However, Yoon and Starks (1995) document evidence inconsistent with this theory in their study of capital expenditures following dividend changes.

As prior evidence is mixed on dividend policy, we use the onset of deregulation in the electric utility industry to explore the motivations of managers as they set their dividend policies. As the firms in the electric utility industry began to face competitive pressures, they might change their dividend policies to more closely resemble other unregulated industries. Their response to deregulation may provide a useful setting to examine some of the research questions associated with dividend policy.

\section{Institutional Background on the Electric Utility Industry}

The first hint of competition in the industry was the enactment of the Public Utilities Regulatory Policies Act of 1978 (PURPA) which encouraged the growth of non-utility power production. However, power producers were not allowed to contract with customers or to sell outside the service area of the host utility. A major step towards introducing competition in the industry was taken in 1992 with the enactment of the Energy Policy Act which removed legal restrictions on electric utilities forming corporate subsidiaries to produce and sell power at the wholesale level. The Act also gave the Federal Energy Regulatory Commission the authority to require a utility to provide other power suppliers access to its transmission system for wholesale power sales across regional lines. Since the passage of the 1992 Act many state legislatures have initiated measures to introduce competition at the retail level. These measures usually allow for "retail wheeling," i.e., giving access of a utility's transmission facilities to a competitor to deliver power to retail customers.

Until the power crisis in California in the summer of 2001, which many attributed to a flawed deregulation process, and the Enron debacle, deregulation in the electric utility industry appeared to be an inevitable process. The process was slowed by these two events. We use the year 1992, the year of the enactment of the Energy Policy Act, as the cut-off between a period in which electric utilities operated in a regulated environment and one where competition was either already present or appeared imminent. (Note 2) 


\section{Research Questions and Methodology}

\subsection{Multivariate Tests of Factors Associated with Dividend Yield and Payout}

Utilities have occasionally cut dividends; however, the cut could clearly be traced to the financial effects of identifiable construction projects. Smith (1986) hypothesizes that a major reason that regulated firms pay high dividends is because doing so forces them to approach the capital markets on a regular basis which serves as a monitoring mechanism. Smith and Watts (1992) and Hansen et al. (1994) test this capital market monitoring hypothesis and find evidence consistent with Smith (1986)'s prediction. With the onset of deregulation and the consequent decline in the power and influence of the regulators, the necessity of such monitoring may be reduced. If the principal reason for high utility dividends is to facilitate this monitoring, we hypothesize that dividend payouts should decline after the onset of deregulation. As deregulation progresses, utilities' growth opportunities will likely increase and utilities may decrease their dividends in order to take advantage of these opportunities.

Prior research (e.g., Elton and Gruber, 1970; Allen et al., 2000; Graham and Kumar, 2006; Brav et al., 2005) also predicts and documents the existence of investor clienteles for high and low dividend paying stock and suggests that factors such as taxes could induce these clienteles. Therefore, firms might be reluctant to change their dividend policies to avoid displeasing their existing clienteles. As we are unsure how utilities have responded to deregulation in terms of their dividend policies, our first hypothesis, stated in null form is:

H1: After deregulation, there will be no change in the level of dividends for utility firms.

We test this conjecture by examining the level of dividends for firms both in the regulated and deregulated regimes. We control for factors identified in prior research as affecting the level of dividends. Specifically, we estimate the following equation in a sample of firms in all industries:

$$
\begin{aligned}
& D_{I V}=\propto+\beta_{i t} \text { Post-EPA }_{t}+\beta_{2} \text { Utility }_{i, t}+\beta_{3} \text { Post-EPA }_{t} * \text { Utility }_{t}+\beta_{4} \text { Size }_{i t}+\beta_{5} \text { Profit }_{i t}+\beta_{6} \text { Lever }_{i t} \\
& +\beta_{7} \text { Growth }_{i t}+\beta_{8} \text { Tobin }_{i t}+\beta_{9} \text { Repurchases }_{i t}+\varepsilon_{i t}
\end{aligned}
$$

where for firm $i$ and year $t, D I V_{i t}$ is either annual dividends per share, dividend yield or the dividend payout ratio. Post-EPA $A_{t}$ is a dummy variable which takes the value one in periods after 1991 and zero otherwise. Utility $y_{i, t}$ is a dummy variable that takes the value one if the observation pertains to an electric utility, zero otherwise. Size $e_{i t}$ is the natural logarithm of the market value of the firm's equity. Profit $t_{i t}$, a proxy for the firm's profitability, is return on equity when the dependent variable is either dividend yield or dividend payout and is EPS when the dependent variable is dividends per share. Lever ${ }_{i t}$, a proxy for the firm's financial leverage, is the ratio of the firm's total liabilities to its total assets. Growth ${ }_{i t}$, a proxy for the firm's growth during the year, is the ratio of the firm's change in total assets scaled by total assets at the beginning of the year. Tobin ${ }_{i t}$ is a proxy for investment opportunities available to the firm, measured as the ratio of the sum of market value of common equity and the book value of debt to the book value of total assets. (Note 3) Repurchases it $_{\text {it }}$ the dollar value of the firm's share repurchases scaled by income before extraordinary items for the year.

This research design allows us to test for changes in dividend policies of electric utilities between periods, controlling for economy-wide changes in dividend policy such as the one documented by Fama and French (2001). To examine the effect of deregulation on electric utility dividends, we include the dummy variables POST-EPA $\left(\beta_{1}\right)$ and UTILITY $\left(\beta_{2}\right)$ and their interaction $\left(\beta_{3}\right)$ in the regression. As utilities tend to pay high dividends, we expect a positive coefficient on $\beta_{2}$. If electric utilities have reduced dividends in the deregulated period, we would expect a negative coefficient on the interaction term. We include a size proxy in the regression because Fama and French (2001) find that firm size is positively associated with the propensity to pay dividends. We include PROFIT to capture effects of firm profitability on the level of dividends (e.g., Jensen et al (1992)). We expect a positive coefficient as more profitable firms can pay dividends. The free cash flow theory suggests that highly levered firms have less need to pay dividends to resolve agency conflicts between owners and managers. We include LEVER to control for the effect of financial leverage on dividend policy and expect a negative coefficient.

The free cash flow theory also suggests that firms' dividend policy should be related to their investment opportunities. Firms with numerous positive NPV investment opportunities would not need to use dividends to resolve agency conflicts between managers and owners. Firms with few such opportunities could use high dividends to signal that they are not investing in value destroying projects. We include two proxies for future investment opportunities: GROWTH which proxies for firms' growth in the recent past, and TOBIN, a forward looking measure of the market's evaluation of firms' prospects (e.g., Fama and French, 2001). Some prior research suggests that share repurchases and dividends are substitutes for each other in returning cash to shareholders. We include REPURCHASES to control for this effect. In order to test for changes in electric utilities dividend paying behavior 
after deregulation, we use three measures of dividends as the dependent variable: dividends per share, dividend yield and the dividend payout ratio.

\subsection{Stock Market Reaction to Electric Utility Dividend Changes}

Prior research has found that dividend increases (decreases) are accompanied by a positive (negative) stock price reaction (see for e.g., Bajaj and Vijh, 1990). This finding is consistent with both the dividend signaling theory and the free cash flow theory. Under the dividend signaling theory, firms use dividend increases (decreases) to convey to the market their favorable (unfavorable) future prospects. Under the free cash flow theory, dividend increases preclude firms from investing free cash flows in negative NPV projects and are therefore good news. Neither of these theories predicts abnormal returns to dividend changes by electric utilities in the regulated era. Management did not need to use dividends to signal future earnings since investors were aware these future earnings were assured by the regulatory contract. The regulatory contract and the rate-setting mechanism also implied that all investments were essentially zero NPV and therefore shareholders could not be hurt by over or under-investment. In the regulated regime, therefore, dividend changes should not have lead investors to make inferences about utilities' long-term prospects.

As the protection afforded to investors by the rate-of-return regulatory system is eroded, changes in dividends are more likely to contribute to investor uncertainty and result in changes in investor clientele. A fair rate of return on investments is no longer assured and electric utilities are no longer precluded from making negative NPV investments. Therefore, we hypothesize that:

H2: Dividend changes are associated with stronger stock price reactions in the deregulated period than in the regulated period.

We investigate the stock market reaction to news of dividend changes in the industry through a series of regressions where the dependent variable is the cumulative abnormal stock return (CAR) in the two-day period ending on the dividend announcement date. Although our focus is on electric utilities, our sample is comprised of firms in all industries to control for changes, between periods, in the market's reactions to dividend changes across all firms. We first estimate the model:

$$
\begin{gathered}
\text { CAR }_{i t}=\alpha+\beta_{1} \text { Utility }_{i t}+\beta_{2} \text { Chdiv }_{i t}+\beta_{3} \text { Post-EPA }_{i t}+\beta_{4} \text { Utility }_{i t} * \text { Chdiv }_{i t}+\beta_{5} \text { Utility }_{i t} * \text { Post }_{\text {EPA }} \text { A }_{i t}+ \\
\beta_{6} \text { Chdiv }_{i t} *{\text { Post }-E P A_{i t}}+\beta_{7} \text { Utiltiy }_{i t} * \text { Chdiv }_{i t} * \text { Post-EPA }_{i t}+\beta_{8} \text { Yield }_{i t}+\varepsilon_{i t}
\end{gathered}
$$

where $C A R_{i t}$ is the cumulative abnormal stock return for firm $i$ over the two-day window ending on the day of the dividend announcement for quarter $t$. Chdiv $v_{i t}$ is the change in dividends for firm $i$ for quarter $t$ scaled by the dividend in quarter $t-1$. Yield ${ }_{t}$ is the dividend yield for firm $i$ in quarter $t$ defined as the dividend in quarter $t$ divided by the stock price at the end of quarter $t$. Other variables are as defined earlier.

We include UTILITY $\left(\beta_{1}\right)$ and the interaction of UTILITY with POST-EPA $\left(\beta_{5}\right)$ in the regression to control for any differential abnormal return to electric utilities in either the regulated or the deregulated periods, respectively. $\beta_{2}$ captures the abnormal returns associated with dividend changes by non-utilities in the pre-1992 period. Both the signaling and the free cash flow theories predict a positive coefficient on this coefficient since dividend increases (decreases) convey good (bad) news for these firms under either theory. POST-EPA controls for any systematic difference in abnormal return in the later period. We expect reactions to dividend changes by electric utilities to be more muted in the regulated era and therefore expect a negative coefficient on $\beta_{4}$. Following the same logic, we expect stronger reactions to electric utility dividend changes after deregulation and therefore expect a positive coefficient on $\beta_{7}$. $\beta_{6}$ captures systematic differences in reactions to dividend changes by non-utilities in the post-1991 era. As Fama and French (2001) document firms' declining propensity to pay dividends in recent years we expect a negative coefficient on $\beta_{6}$. Bajaj and Vijh (1990) find that, because of clientele effects, abnormal stock returns around dividend changes are related to the dividend yield with the reaction being more pronounced for high dividend yield firms. The variable YIELD controls for this effect.

Prior studies have found that the magnitude of the stock price reaction to news of dividend changes differs depending on whether the change is an increase or a decrease. The reaction was found to be stronger for dividend decreases than for dividend increases. To examine whether this asymmetric reaction exists in our sample, we estimate:

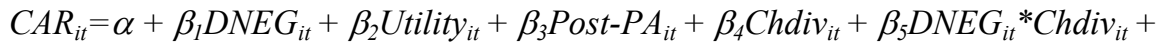

$$
\begin{aligned}
& \beta_{6} D_{N E G_{i t}}{ }^{*} \text { Post-EPA }_{i t}+\beta_{7} \text { DNEG }_{i t}{ }^{*} \text { Utility }_{i t}+\beta_{8} \text { Post-EPA }_{i t}{ }^{*} \text { Utility }_{i t}+\beta_{9}{ }^{*} \text { Post-EPA }_{i t} * \text { Chdiv }_{i t}+ \\
& \beta_{10} \text { Utility }_{i t}{ }^{*} \text { Chdiv }_{i t}+\beta_{11} \text { DNEG }_{i t}{ }^{*} \text { Post-EPA }_{i t}{ }^{*} \text { Utility }_{i t}+\beta_{12} \text { DNEG }_{i t}{ }^{*} \text { Utility }_{i t} * \text { Chdiv }_{i t}+ \\
& \beta_{13} D_{N E G_{i t}}{ }^{*}{\text { Post }-E P A_{i t}}^{*}{ }^{2} \text { Chdiv } v_{i t}+\beta_{14}{ }^{*}{\text { Post }-E P A_{i t}}^{*} \text { Utility }_{i t}{ }^{*} \text { Chdiv }_{i t}+ \\
& \beta_{15} D_{N E G_{i t}}{ }^{*} \text { Post-EPA }_{i t}{ }^{*} \text { Utility }_{i t}{ }^{*} \text { Chdiv }_{i t}+\beta_{16} \text { Yield }_{i t}+\varepsilon_{i t}
\end{aligned}
$$


where $\mathrm{DNEG}_{\mathrm{it}}$ is a dummy variable that takes the value one when there is a decrease in dividends and zero otherwise, and the other variables are as defined earlier. (Note 4) If the magnitude of the stock reaction to dividend decreases differs from that for dividend increases, we would expect the interactions of DNEG with the dividend change variable, CHDIV, to be statistically significant.

Findings in prior research of abnormal returns around dividend changes are consistent with both the signaling theory for dividends and the theory that firms use dividends to resolve agency conflicts between managers and investors. To distinguish between these two theories, we examine if abnormal returns for electric utilities around dividend change announcements vary depending on the investment opportunities available to the firm. The free cash flow theory predicts differences based on investment opportunities while the signaling theory does not. One of the implications of the free cash flow theory is that the market reaction to dividend changes should differ depending on the investment opportunities available to the firm. Increases in dividends should be interpreted negatively (positively) for firms with (without) attractive investment opportunities.

Deregulation is likely to have increased both the business risk and the investment opportunity sets of electric utilities. Increase in business risk may have raised the cost of capital for electric utilities making internally generated cash flow more attractive. Dividend reductions free up cash to invest in newly available investment opportunities. It is conceivable that the market reaction to news of dividend changes is dependent on whether investment opportunities available to individual electric utilities are perceived to be positive NPV. Lang and Litzenberger (1989) find that the abnormal returns associated with dividend changes are greater when firms are likely to be over-investing (defined as firms with Tobin's Q less than 1). They interpret this as evidence in favor of the free cash flow hypothesis. Smith and Watts (1992) document that firms with fewer growth options have higher dividend payouts. To investigate the effect of growth opportunities on the stock reaction to dividend changes we estimate the following regression:

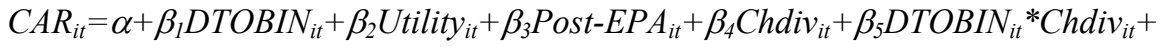

$$
\begin{aligned}
& \beta_{6} \text { DTOBIN }_{i t}{ }^{*} \text { Post-EPA }_{i t}+\beta_{7} \text { DTOBIN }{ }_{i t} * \text { Utility }_{i t}+\beta_{8} \text { Post-EPA }^{*} \text { Utility }_{i t}+\beta_{9} * \text { Post-EPA }_{i t} * \text { Chdiv }_{i t}+ \\
& \beta_{10} \text { Utility }_{i t} * \text { Chdiv }_{i t}+\beta_{11} \text { DTOBIN }_{i t} * \text { Post-EPA }_{i t} * \text { Utility }_{i t}+\beta_{12} \text { DTOBIN }_{i t} * \text { Utility }_{i t} * \text { Chdiv }_{i t}+ \\
& \beta_{13} \text { DTOBIN }_{i t} * \text { Post-EPA }_{i t} * \text { Chdiv }_{i t}+\beta_{14} \text { Post-EPA }_{i t} * \text { Utility }_{i t} * \text { Chdiv }_{i t}+ \\
& \beta_{15} \text { DTOBIN }_{i t} * \text { Post-EPA }_{i t} * \text { Utility }_{i t} * \text { Chdiv }_{i t}+\beta_{16} \text { Yield }_{i t}+\varepsilon_{i t}
\end{aligned}
$$

where DTOBIN $\mathrm{it}_{\text {it }}$ is an indicator variable that takes the value 1 when the Tobin's Q for firm $i$ in the year in which quarter $t$ falls is higher than the median for the year, and zero otherwise. Other variables are as defined earlier.

If stock price responses to dividend changes differ for firms based on their growth opportunities, as implied by the free cash flow theory, we would expect significant coefficients on the interactions of DTOBIN with the dividend change variable, CHDIV. In particular, we would expect a negative and significant coefficient on DTOBIN*CHDIV. If the information content of dividend changes is not as strongly linked to investment opportunities for electric utilities prior to deregulation, we expect a positive and significant coefficient on DTOBIN*UTILITY*CHDIV.

\subsection{Earnings Changes around Dividend Changes}

The signaling theory for dividends suggests that managers use dividends to signal future cash flows and earnings. Prior research has examined whether dividend changes are associated with the predicted earnings changes and found mixed results (Note 5). We predict that, if utilities use dividends to signal future earnings, this signaling is more likely to occur in the post-deregulation period. Earnings were more predictable in the regulated regime and the need to signal is likely to have been lower. Therefore we hypothesize,

H3: Dividend changes should be associated with earnings changes in the deregulated period but not in the regulated period.

We examine the behavior of earnings for utilities in the years surrounding dividend changes. Using a linear regression framework to examine the dividend signaling theory, we estimate the following model:

$$
\begin{gathered}
\text { IBEI }_{t+i}=\alpha+\beta_{1} \text { Utility }_{t}+\beta_{2}{\text { Post }-E P A_{t}}+\beta_{3} \text { Chdiv }_{t}+\beta_{4} \text { Utility }_{t}{ }^{*}{\text { Post }-E P A_{t}}+\beta_{5} \text { Utility }_{t} * \text { Chdiv }_{t}+ \\
\beta_{6}{\text { Post }-E P A_{t}}^{*} \text { Chdiv }_{t}+\beta_{7} \text { Utility }_{t}{ }^{*}{\text { Post }-E P A_{t}}^{*} \text { Chdiv }_{t}+\varepsilon_{t}
\end{gathered}
$$

where $\mathrm{IBEI}_{\mathrm{t}+\mathrm{I}}$ is the percentage change in income before extraordinary items between year $\mathrm{t}$ and year $\mathrm{t}+\mathrm{i}$, for $\mathrm{i}=1$ to 3. Other variables are as defined earlier.

Dividend signaling among non-electric utility firms would predict positive and significant coefficients on $\beta_{3}$, and $\beta_{6}$. If electric utilities did not signal their future prospects through dividend changes in the regulated regime but had 
greater need to signal these prospects after the onset of deregulation, we would expect a positive and significant coefficient on $\beta_{7}$.

\subsection{Sample and Data}

We obtain two samples for each test in order to determine if utilities perform differently from a set of general firms. For our utility sample, we identify electric utilities as firms in SIC codes 4910, 4911, 4930 or 4931 in the COMPUSTAT and Center for Research on Security Prices (CRSP) databases. The other sample was for a general sample of firms excluding utilities. We extract dividends and returns data from the CRSP database for the period 1962-2004, and accounting data from the COMPUSTAT database for the period 1985-2004.

In Table 1, we present a comparison of metrics for our sample of electric utilities for the years prior to the enactment of the 1992 Energy Policy Act and the years after the onset of deregulation. To facilitate comparison, we also present these metrics for non-electric utilities labeled 'other firms' in the table. The median values of the price to earnings ratio has increased between the pre- and the post deregulation period. This could be a result of the market recognizing the greater growth opportunities or greater efficiency of electric utilities after deregulation. Alternatively, this could reflect the generally higher valuations in the later period as the 'other firms' sample show an increase in this ratio over the period. However, the ratio reflecting profitability, return on equity, is lower for the utility sample in the later period. It is possible that pricing pressures associated with a competitive market after deregulation is responsible for the decreased profitability. Alternatively, as the 'other firms' sample also exhibits decreases in this ratio, this decrease could be associated with economy-wide trends.

The debt to equity ratio of electric utilities has increased between periods indicating that utilities have taken on more debt. Increases in leverage after deregulation reduce free cash flows and are consistent with the free cash flow theory. This trend is not reflected in the sample of other firms as the debt to equity ratios in this latter sample have marginally declined. The increase in debt in the utilities sample does not appear to be to fund their expansion programs. Electric utilities asset growth has slowed in the later period, both in relation to the earlier period and in relation to the 'other firms' sample.

Table 1. Descriptive statistics of selected metrics of electric utilities in our sample

\begin{tabular}{|c|c|c|c|c|c|c|c|}
\hline \multirow[b]{2}{*}{ Panel $A$} & \multirow[t]{2}{*}{ Ratio } & \multicolumn{3}{|c|}{ Pre-EPA } & \multicolumn{3}{|c|}{ Post-EPA } \\
\hline & & $Q 1$ & Median & $Q 3$ & $Q 1$ & Median & $Q 3$ \\
\hline \multirow{9}{*}{$\begin{array}{c}\text { Electric } \\
\text { Utility } \\
\end{array}$} & Price to Earnings & 7.05 & $9.24 * \#$ & 11.97 & 11.81 & $13.88^{* \#}$ & 16.55 \\
\hline & & & & & & & \\
\hline & Return on Equity (\%) & 12.33 & $13.91 * \#$ & 15.46 & 9.05 & $11.83 * \#$ & 13.61 \\
\hline & Market capitalization & 4.90 & $5.92 * \#$ & 6.80 & 6.61 & $7.68 * \#$ & 8.54 \\
\hline & Tobin's Q & 0.96 & $1.03 * \#$ & 1.13 & 1.07 & $1.15 * \#$ & 1.24 \\
\hline & Debt/Equity & 1.40 & $1.59 * \#$ & 1.81 & 1.70 & $2.11 * \#$ & 2.76 \\
\hline & Asset Growth (\%) & 3.82 & $8.09 *$ & 12.83 & -8.50 & $2.84 * \#$ & 8.17 \\
\hline & Dividend payout (\%) & 53.11 & $60.02 * \#$ & 67.66 & 54.32 & $70.98 * \#$ & 84.56 \\
\hline & Dividend yield (\%) & 5.77 & $7.67 * \#$ & 9.78 & 3.55 & $5.09 * \#$ & 6.32 \\
\hline \multicolumn{8}{|l|}{ Panel B } \\
\hline \multirow[t]{8}{*}{ Other Firms } & Price to Earnings & 7.55 & $11.77 * \#$ & 19.23 & 11.59 & $16.88 * \#$ & 26.87 \\
\hline & Return on Equity (\%) & 1.89 & $10.55^{* \#}$ & 16.79 & -8.24 & $8.11 * \#$ & 16.64 \\
\hline & $\begin{array}{l}\text { Market capitalization } \\
\quad(\text { million } \$ s)\end{array}$ & 2.15 & $3.45 * \#$ & 4.90 & 3.06 & $4.57 * \#$ & 6.15 \\
\hline & Tobin's Q & 0.93 & $1.12 * \#$ & 1.65 & 1.04 & $1.39 * \#$ & 2.37 \\
\hline & Debt/Equity & 0.50 & $1.09 * \#$ & 2.14 & 0.30 & $1.00 * \#$ & 2.61 \\
\hline & Asset Growth (\%) & -1.93 & $7.99 *$ & 21.08 & -4.85 & $7.04 * \#$ & 26.67 \\
\hline & Dividend payout (\%) & 0.00 & $14.31 * \#$ & 37.33 & 0.00 & $0.00 * \#$ & 32.22 \\
\hline & Dividend yield (\%) & 0.00 & $0.00 * \#$ & 3.37 & 0.00 & $0.00 * \#$ & 1.14 \\
\hline
\end{tabular}


Notes: Ratios are defined as follows (data item numbers refer to data item numbers in the COMPUSTAT annual database): Price to earnings is stock price at close of fiscal year (data item 199)/ Primary earnings per share excluding extraordinary items (data item 58). Return on equity is income before extraordinary items (data item 18)/ Total common equity (data item 60). Market capitalization is the log of (Closing stock price (data item 24) $\mathrm{x}$ Common shares outstanding (data item 25)). Tobin's Q is (Market value of common equity + Book value of debt) divided by book value of total assets (data item $6+$ data item $24 \times$ data item 25 - data item 60)/data item 6). Debt to Equity ratio is total liabilities (data item 181) / Total stockholders equity (data item 6 - data item 181). Asset Growth is total assets (data item 6) - prior years total assets (data item 6)/prior years total assets. Dividend payout ratio is common dividends (data item 21)/ Income before extraordinary items (data item 18). Dividend yield is dividends per share by ex-date (data item 26)/ Stock price at close of fiscal year (data item 199).

* Difference between pre-and post EPA period is significant at the $1 \%$ level in the Mann-Whitney test.

\# Difference between electric utilities and non-electric utilities significant at the $1 \%$ level in the Mann-Whitney test.

The univariate statistics suggest that utilities actually increased dividend payout between the regulated and the deregulated period. As noted earlier, profitability declined between the two periods for utilities and firms that maintained their dividend level stable are likely to have seen their dividend payout ratio trending upwards. This is preliminary evidence in favor of the 'clientele' theory for dividend policy. Firms appear to be unwilling to reduce dividends even as profitability declines. This phenomenon is not reflected in the 'other firms' sample with payouts in this sample declining between periods. This latter finding is in line with Fama and French (2001) who document a declining propensity to pay dividends which is discernible across industries. It is also evident that electric utilities continue to pay out a considerably larger proportion of earnings as dividends than firms in the 'other firms' sample. However, utilities' dividend yield has declined between periods. This could be related to the higher stock valuations relative to earnings in the deregulated period reflected in the higher price to earnings ratios.

\section{Empirical Results}

\subsection{Estimation Results for Equation (1)}

Table 2 presents the results of estimating equation (1). Panel A reports the results when the dependent variable is dividends per share, panel $\mathrm{B}$ the results when it is dividend yield and panel $\mathrm{C}$ when it is the dividend payout ratio. The first column in each panel of the table reports results using ordinary least squares (OLS) regressions. The second column reports results estimated using generalized estimating equations (GEE) which adjusts for clustering of observations by firm (Note 6).

In both estimations in Panel A, the coefficient on POST-EPA is negative and statistically significant at less than the 1\% level, suggesting that dividends per share have decreased for all firms in recent years. This is consistent with the findings of Fama and French (2001) who detect a declining propensity of firms to pay dividends across all firms. Similarly, the coefficient on UTILITY is positive and strongly significant in both estimations confirming findings in Smith and Watts (1992) that electric utilities paid higher dividends than other firms prior to deregulation. The results for the interaction term are not significant at conventional levels in the OLS and GEE estimations suggesting no changes in dividends per share associated with deregulation. The control variables, for the most part, manifest expected signs and are statistically significant. One of the implications of the free cash flow theory is that leverage and dividends are substitutes in dealing with the agency problems associated with free cash flows. Our results do not support this implication. LEVER is positive and significant. However, the results for GROWTH and TOBIN are supportive of the free cash flow theory. Both these variables are negative and significant indicating that firms that are investing heavily in assets and those with better growth prospects pay lower dividends. Our results suggest that firms that pay high dividends are more likely to return cash to shareholders through share repurchases.

Panel B presents the results when the dependent variable is dividend yield. The results are similar to those in Panel A with one exception. The interactive term UTILITY*POST-EPA is negative and significant suggesting that dividend yield for electric utilities has decreased between periods. The results in Panel A indicate that dividends per share for electric utilities were stable between periods. The results in Panel B suggest that the denominator of dividend yield, the stock price has increased more for electric utilities than for other firms. 
Table 2. Factors associated with dividends

\begin{tabular}{|c|c|c|c|c|c|c|c|}
\hline Dependent Variable: & & \multicolumn{2}{|c|}{$\begin{array}{c}\text { Panel A: } \\
\text { Dividends Per }\end{array}$} & \multicolumn{2}{|c|}{ Panel B: } & \multicolumn{2}{|c|}{ Panel C: } \\
\hline$V A R I A B L E$ & $\begin{array}{l}\text { Predicted } \\
\text { sign }\end{array}$ & $O L S$ & $G E E$ & $O L S$ & $G E E$ & $O L S$ & $G E E$ \\
\hline Intercept & & $\begin{array}{c}0.042 \\
(0.0001)\end{array}$ & $\begin{array}{c}0.036 \\
(0.0001)\end{array}$ & $\begin{array}{c}1.251 \\
(0.0001)\end{array}$ & $\begin{array}{c}1.161 \\
(0.0001)\end{array}$ & $\begin{array}{c}14.243 \\
(0.0001)\end{array}$ & $\begin{array}{c}13.271 \\
(0.0001)\end{array}$ \\
\hline Post-EPA & - & $\begin{array}{c}-0.097 \\
(0.0001)\end{array}$ & $\begin{array}{c}-0.084 \\
(0.0001)\end{array}$ & $\begin{array}{c}-1.208 \\
(0.0001)\end{array}$ & $\begin{array}{c}-0.941 \\
(0.0001)\end{array}$ & $\begin{array}{c}-7.418 \\
(0.0001)\end{array}$ & $\begin{array}{c}-5.950 \\
(0.0001)\end{array}$ \\
\hline Utility & + & $\begin{array}{c}0.867 \\
(0.0001)\end{array}$ & $\begin{array}{c}0.872 \\
(0.0001)\end{array}$ & $\begin{array}{c}6.235 \\
(0.0001)\end{array}$ & $\begin{array}{c}6.285 \\
(0.0001)\end{array}$ & $\begin{array}{c}25.098 \\
(0.0001)\end{array}$ & $\begin{array}{c}27.134 \\
(0.0001)\end{array}$ \\
\hline Utility *Post-EPA & $?$ & $\begin{array}{l}-0.010 \\
(0.46)\end{array}$ & $\begin{array}{l}0.012 \\
(0.78)\end{array}$ & $\begin{array}{c}-3.073 \\
(0.0001)\end{array}$ & $\begin{array}{c}-2.937 \\
(0.0001)\end{array}$ & $\begin{array}{c}11.361 \\
(0.0001)\end{array}$ & $\begin{array}{c}10.709 \\
(0.0001)\end{array}$ \\
\hline Size & + & $\begin{array}{c}0.055 \\
(0.0001)\end{array}$ & $\begin{array}{c}0.053 \\
(0.0001)\end{array}$ & $\begin{array}{c}0.257 \\
(0.0001)\end{array}$ & $\begin{array}{c}0.193 \\
(0.0001)\end{array}$ & $\begin{array}{c}4.349 \\
(0.0001)\end{array}$ & $\begin{array}{c}3.990 \\
(0.0001)\end{array}$ \\
\hline Profit & + & $\begin{array}{c}0.034 \\
(0.0001)\end{array}$ & $\begin{array}{c}0.024 \\
(0.0001)\end{array}$ & $\begin{array}{c}0.145 \\
(0.0001)\end{array}$ & $\begin{array}{c}0.089 \\
(0.0001)\end{array}$ & $\begin{array}{c}-4.221 \\
(0.0001)\end{array}$ & $\begin{array}{c}-7.235 \\
(0.0001)\end{array}$ \\
\hline Leverage & - & $\begin{array}{c}0.001 \\
(0.0001)\end{array}$ & $\begin{array}{l}0.001 \\
(0.03)\end{array}$ & $\begin{array}{c}0.009 \\
(0.0001)\end{array}$ & $\begin{array}{c}0.008 \\
(0.002)\end{array}$ & $\begin{array}{c}0.328 \\
(0.0001)\end{array}$ & $\begin{array}{c}0.438 \\
(0.0001)\end{array}$ \\
\hline Growth & - & $\begin{array}{c}-0.040 \\
(0.0001) \\
\end{array}$ & $\begin{array}{c}-0.030 \\
(0.0001) \\
\end{array}$ & $\begin{array}{c}-0.255 \\
(0.0001)\end{array}$ & $\begin{array}{c}-0.168 \\
(0.0001)\end{array}$ & $\begin{array}{c}-6.270 \\
(0.0001)\end{array}$ & $\begin{array}{c}-4.233 \\
(0.0001)\end{array}$ \\
\hline Tobin's Q & - & $\begin{array}{c}-0.011 \\
(0.0001)\end{array}$ & $\begin{array}{c}-0.010 \\
(0.0001)\end{array}$ & $\begin{array}{c}-0.118 \\
(0.0001)\end{array}$ & $\begin{array}{c}-0.093 \\
(0.0001)\end{array}$ & $\begin{array}{c}-2.654 \\
(0.0001)\end{array}$ & $\begin{array}{c}-2.447 \\
(0.0001)\end{array}$ \\
\hline Repurchases & - & $\begin{array}{c}0.026 \\
(0.0001)\end{array}$ & $\begin{array}{c}0.023 \\
(0.0001)\end{array}$ & $\begin{array}{l}-0.044 \\
(0.002)\end{array}$ & $\begin{array}{l}0.008 \\
(0.52)\end{array}$ & $\begin{array}{c}5.862 \\
(0.0001)\end{array}$ & $\begin{array}{c}7.365 \\
(0.0001)\end{array}$ \\
\hline No. of observations & & 176,546 & 176,546 & 175,504 & 175,504 & 121,062 & 121,062 \\
\hline R-squared (\%) & & 27.87 & & 22.49 & & 7.21 & \\
\hline Log-likelihood & & & $-85,976$ & & $-403,754$ & & $-637,119$ \\
\hline
\end{tabular}

Notes: Variables, excluding indicator variables, are winsorized at the $1 \%$ and the $99 \%$ levels. p-values in parentheses.

\section{Variable definitions:}

Yield Dividend yield computed as the ratio of the annual dividend to stock price

Payout Dividend payout ratio computed as the ratio of annual dividends to earnings before extraordinary items

Post-EPA Indicator variable that takes the value one when the observation is for a year after 1991, zero otherwise Size Logarithm of market value of equity in millions of dollars.

Profit ROE computed as income before extraordinary items scaled by scaled by stockholders' equity or EPS

Lever Total liabilities divided by total shareholders' equity

Growth Change in total assets during the year scaled by total assets in the prior year

Tobin's Q (Market value of common equity + Book value of debt) divided by book value of total assets

Utility Indicator variable that takes the value one when the observation is for an electric utility, zero otherwise Repurchases Share repurchases during the year scaled by income before extraordinary items. 
Panel $\mathrm{C}$ of Table 2 presents the results when the dependent variable is the dividend payout ratio. The results are similar to those reported in panels A and B with the following exception. The interaction of UTILITY and POST-EPA is positive and significant in both columns. Controlling for market wide changes, the dividend payout ratio has increased for electric utilities after deregulation. This finding is consistent with some prior research that has documented the existence of dividend clienteles (e.g., Elton and Gruber, 1970, Allen et al., 2000, Graham and Kumar, 2006). It is possible that electric utilities might have maintained their high level of dividends, to retain their high-dividend clientele, despite declining profitability. This would explain the increase in their payout ratio. Lintner (1956) found that firms appear to adjust their dividends towards a target dividend payout ratio. However, more recent survey evidence in Brav et al. (2005) suggests that firms prefer to pay stable levels of dividends rather than targeting a specific payout ratio. The results in Panels A and C are consistent with this latter study.

Overall, the results in this section indicate that the advent of competition has not induced electric utilities to reduce their levels of dividends. They appear to be maintaining this level even as profitability declines. We interpret this as evidence in favor of dividend clienteles influencing electric utilities' dividend policies. Our results for the GROWTH and TOBIN variables, but not for the LEVER variable, also provide support for the theory that dividends play a role in resolving agency conflicts between managers and shareholders (Note 7).

\subsection{Empirical Results of Tests Related to Abnormal Returns around Dividend Change Announcements}

Table 3 presents the median announcement period abnormal returns categorized by the sign of the change in dividends. Dividend changes are categorized as increases (decreases) if they were greater (less) than 10\% (-10\%). Dividends were judged to be unchanged if there was no change in dividends between adjacent quarters. Abnormal returns are measured using two alternative methods. First, excess returns are computed as the difference between returns for the firm and returns for a portfolio of firms in the same beta decile. The alternative measure of abnormal returns uses the difference between the return on the firm's stock and the return on a value weighted market portfolio. To facilitate comparison, abnormal returns are also computed for all dividend announcements by non-electric utility firms on CRSP. We use a two-day event window consisting of the day prior to and the day of the dividend announcement.

Consistent with prior research, in the 'other firms' sample and in both periods, we find statistically significant positive (negative) abnormal returns for dividend increases (decreases). In addition, the reaction to dividend decreases is stronger than to dividend increases in the earlier period. However, in the later period, the magnitude of the reaction to dividend increases is greater than that for decreases in the later period. We also observe that the magnitudes of these abnormal returns have declined between periods. In recent years, the market does not appear to interpret dividend increases (decreases) as good (bad) news to the same extent as it did in prior years.

Table 3. Abnormal returns following dividend changes

Panel A. Beta excess returns

\begin{tabular}{lllllll}
\hline & \multicolumn{3}{c}{ ELECTRIC UTILITIES } & & OTHER FIRMS \\
\hline Median & $\begin{array}{l}\text { Dividend } \\
\text { decrease }\end{array}$ & no change & $\begin{array}{l}\text { Dividend } \\
\text { increase }\end{array}$ & $\begin{array}{l}\text { Dividend } \\
\text { decrease }\end{array}$ & no change & $\begin{array}{l}\text { Dividend } \\
\text { increase }\end{array}$ \\
\hline Pre -EPA & -0.04 & -0.03 & $0.52^{* * *}$ & $-1.87^{* * *}$ & $-0.12^{* * *}$ & $0.99 * * *$ \\
\hline Sample size & 283 & 6,823 & 460 & 2,257 & 116,682 & 13,019 \\
\hline Post - EPA & 0.40 & $0.02 *$ & $0.36^{* *}$ & $-0.32 * * *$ & $-0.04 * *$ & $0.48^{* * *}$ \\
\hline Sample size & 61 & 3,310 & 59 & 1,464 & 48,219 & 4,528 \\
\hline
\end{tabular}

Panel B. Market adjusted returns

\begin{tabular}{lllllll}
\hline & ELECTRIC UTILITIES & \multicolumn{5}{l}{ OTHER FIRMS } \\
\hline Median & $\begin{array}{l}\text { Dividend } \\
\text { decrease }\end{array}$ & no change & $\begin{array}{l}\text { Dividend } \\
\text { increase }\end{array}$ & $\begin{array}{l}\text { Dividend } \\
\text { decrease }\end{array}$ & no change & $\begin{array}{l}\text { Dividend } \\
\text { increase }\end{array}$ \\
\hline Pre -EPA & $0.20^{* *}$ & $0.05^{* * *}$ & $0.93^{* * *}$ & $-1.30^{* * *}$ & $-0.05^{* *}$ & $1.00^{* * *}$ \\
\hline Sample size & 292 & 7,535 & 477 & 3,317 & 172,674 & 19,862 \\
\hline Post - EPA & $0.68^{*}$ & $0.08^{* * *}$ & $0.66^{* *}$ & $-0.14^{* * *}$ & $0.04^{* * *}$ & $0.54^{* * *}$ \\
\hline Sample size & 62 & 3,448 & 59 & 2,076 & 81,290 & 8,716 \\
\hline
\end{tabular}




\section{Notes:}

Abnormal returns (expressed as percentages) are measured over a two-day window ending on the date of the dividend announcement as recorded on CRSP. Beta excess returns are the difference between raw returns and the return on a portfolio of stocks in the same beta decile. Market adjusted returns are raw returns less the return on the market.

*** Significant at the $1 \%$ level $\quad * *$ Significant at the $5 \%$ level $\quad *$ Significant at the $10 \%$ level

The electric utility sample appears to react less strongly to dividend changes in the regulated period. The magnitudes of the median abnormal returns around the announcement dates are considerably lower. This is consistent with the market interpreting dividend changes for regulated electric utilities differently from those of unregulated firms. In the later period, the differences have narrowed, though this is partly a function of the reactions to dividend changes by other firms being more muted in this period. We also note that the reaction to dividend decreases by utilities is positive on average in the later period. These results, however, should be interpreted with caution because we do not take the magnitude of the dividend change into account in these univariate analyses.

The results of estimating the multivariate regressions represented by equations (2), (3) and (4) are presented in Table 4. To reduce noise, the sample is restricted to dividend announcements where there was a change in dividends. We include firms in other industries besides electric utilities to facilitate comparison and to control for trends that affect all firms.

The results of estimating equation (2), using both our measures of abnormal returns around the announcement period as the dependent variable, are presented in Panel A of Table 4. The results are reasonably consistent across both dependent variables. The coefficient on CHDIV is positive and significant indicating that the market interpreted increases (decreases) of dividends as good (bad) news for the 'other firms' sample. The coefficient on CHDIV*POST-EPA is negative and significant suggesting that the market did not respond to dividend changes as strongly in the later period. The coefficient on UTILITY*CHDIV is negative and significant indicating that, consistent with predictions, reactions to utility dividend changes in the regulated regime were considerably smaller in magnitude than for other firms. The coefficient on UTILITY*CHDIV*POST-EPA is positive and significant indicating that, again consistent with predictions, market reactions to utility dividend changes in the deregulated regime are stronger than in the regulated regime. F-tests indicate that changes in electric utility dividends are associated with abnormal stock returns after deregulation. Similar F-tests in the regulated regime suggest weaker evidence of information content. Overall, the results in this panel suggest that the information content of utility dividends has increased after the onset of deregulation.

Panel B presents the results of estimating equation (3) which attempts to discern whether the market reacts symmetrically to dividend increases and decreases, both by electric utilities and by firms in general. Prior research has documented an asymmetric reaction, across all firms, with dividend decreases provoking a stronger market reaction than increases. The coefficient on DNEG*CHDIV is positive and significant which is evidence of this asymmetric reaction in the non-electric utility sample in the earlier period. The coefficient on DNEG*POST-EPA*CHDIV is negative and significant which indicates that the reaction to dividend increases and decreases has become more symmetric for these firms in the later period. Nevertheless an F-test indicates that some asymmetry is still present in the later period. The coefficient on DNEG*UTILITY*CHDIV is negative and significant which suggests that the reaction to dividend increases and decreases was more symmetric for utilities in the regulated regime. F-tests do not reject the hypothesis that the reactions to positive and negative utility dividend changes were symmetric in the regulated period. The coefficient on DNEG*POST-EPA*UTILITY*CHDIV is positive and significant indicating that the reaction has become more asymmetric, i.e., more like other firms in the deregulated regime. The results in this panel again provide support to the idea that the market interprets changes in utility dividends more like they do changes in the dividends of other firms after deregulation.

The results in Panel A are consistent with both the signaling and the free cash flow theories for dividend policy. Estimation of equation 4, helps us to distinguish between these two theories. The results in Panel C provide mixed support for the free cash flow theory. The coefficient on DTOBIN*CHDIV is negative and significant suggesting that the market reaction to dividend increases (decreases) in the earlier period is more negative (positive) for firms with more attractive investment options. This is consistent with the predictions from the free cash flow theory as it applies to dividends and also with Lang and Litzenberger (1989). However, the coefficient on DTOBIN*POST-EPA*CHDIV is positive and significant and its magnitude indicates that this effect is largely 
counteracted in the later period. The F-test does not conclusively reject the hypothesis that the sum of the coefficients on DTOBIN*CHDIV and DTOBIN*POST-EPA*TOBIN is zero. The results for non-electric utilities in the later period are therefore not as supportive of the free cash flow theory. The coefficient on DTOBIN*UTILITY*CHDIV is positive and significantly different from zero (at the $5 \%$ level) suggesting that, in the regulated regime, electric utilities with above average investment opportunities differ from their counterparts in other industries in their reactions to news of dividend changes. The hypothesis that sum of the coefficients on DTOBIN*CHDIV and DTOBIN*UTILITY*CHDIV is zero is not rejected suggesting that market reactions to changes in utility dividends did not depend on investment opportunities in the deregulated regime.

The coefficient on DTOBIN*POST-EPA*UTILITY*CHDIV is, however, not significant at conventional levels indicating that the market reaction to dividend changes by electric utilities with above average investment opportunities do not differ from firms in other industries with similar characteristics in the deregulated period. The F-test also does not offer strong evidence that the market reacts differently to dividend changes by electric utilities with superior investment opportunities in the later period. The market reaction to electric utility dividend changes has become closer to those of other firms consistent with deregulation causing changes in the way investors view utilities. However, because of changes in how investors react to dividend changes of all firms, it is difficult to conclusively interpret this as evidence in favor of the free cash flow theory.

Table 4. Factors associated with announcement period cumulative abnormal returns

\begin{tabular}{|c|c|c|c|c|c|c|c|}
\hline \multirow{3}{*}{$\begin{array}{c}\begin{array}{c}\text { Panel / Estimation of } \\
\text { Equation }\end{array} \\
\text { Variable } \\
\end{array}$} & \multicolumn{3}{|c|}{$A(2)$} & \multicolumn{2}{|c|}{ B (3) } & \multicolumn{2}{|c|}{ C (4) } \\
\hline & \multirow[b]{2}{*}{$\begin{array}{l}\text { Predicted } \\
\text { sign }\end{array}$} & \multicolumn{2}{|c|}{ Dependent variable } & \multicolumn{2}{|c|}{ Dependent variable } & \multicolumn{2}{|c|}{ Dependent variable } \\
\hline & & $\begin{array}{c}\text { Beta excess } \\
\text { return }\end{array}$ & $\begin{array}{c}\text { Market } \\
\text { adjusted } \\
\text { return } \\
\end{array}$ & $\begin{array}{l}\text { Beta } \\
\text { excess } \\
\text { return }\end{array}$ & $\begin{array}{c}\text { Market } \\
\text { adjusted } \\
\text { return } \\
\end{array}$ & $\begin{array}{l}\text { Beta excess } \\
\text { return }\end{array}$ & $\begin{array}{c}\text { Market } \\
\text { adjusted } \\
\text { return } \\
\end{array}$ \\
\hline INTERCEPT & & $\begin{array}{c}-0.449 \\
(-11.02)^{* * *}\end{array}$ & $\begin{array}{c}0.079 \\
(2.63) * * *\end{array}$ & $\begin{array}{c}0.230 \\
(3.95)^{* * *}\end{array}$ & $\begin{array}{c}0.572 \\
(12.52)^{* * *}\end{array}$ & $\begin{array}{c}-0.931 \\
(-14.60)^{* * *}\end{array}$ & $\begin{array}{c}-0.151 \\
(-3.17)^{* * *}\end{array}$ \\
\hline Utility & $?$ & $\begin{array}{c}0.505 \\
(5.09)^{* * *}\end{array}$ & $\begin{array}{c}0.500 \\
(4.95) * * *\end{array}$ & $\begin{array}{l}-0.021 \\
(-0.15)\end{array}$ & $\begin{array}{l}0.135 \\
-0.98\end{array}$ & $\begin{array}{c}0.629 \\
(4.59)^{* * *}\end{array}$ & $\begin{array}{c}0.603 \\
(4.40)^{* * *}\end{array}$ \\
\hline CHDIV & + & $\begin{array}{c}6.602 \\
(45.66)^{* * *} \\
\end{array}$ & $\begin{array}{c}6.197 \\
(48.78)^{* * *} \\
\end{array}$ & $\begin{array}{c}3.393 \\
(14.00)^{* * *} \\
\end{array}$ & $\begin{array}{c}3.764 \\
(18.05)^{* * *} \\
\end{array}$ & $\begin{array}{c}8.814 \\
(39.52)^{* * *} \\
\end{array}$ & $\begin{array}{c}8.377 \\
(41.67)^{* * *} \\
\end{array}$ \\
\hline Post-EPA & $?$ & $\begin{array}{c}0.117 \\
(2.19)^{* *} \\
\end{array}$ & $\begin{array}{r}0.058 \\
-1.24 \\
\end{array}$ & $\begin{array}{c}-0.299 \\
(-3.69)^{* * *} \\
\end{array}$ & $\begin{array}{c}-0.338 \\
(-4.91)^{* * *} \\
\end{array}$ & $\begin{array}{c}0.273 \\
(3.24)^{* * * *} \\
\end{array}$ & $\begin{array}{c}0.179 \\
(2.64)^{* * *}\end{array}$ \\
\hline Utility*Chdiv & - & $\begin{array}{c}-6.110 \\
(-12.31)^{* * *}\end{array}$ & $\begin{array}{c}-5.022 \\
(-9.65)^{* * *} \\
\end{array}$ & $\begin{array}{c}-3.456 \\
(-4.45)^{* * *} \\
\end{array}$ & $\begin{array}{c}-3.359 \\
(-4.15)^{* * *} \\
\end{array}$ & $\begin{array}{c}-7.776 \\
(-12.86)^{* * *} \\
\end{array}$ & $\begin{array}{c}-6.494 \\
(-10.28)^{* * *} \\
\end{array}$ \\
\hline Utility*Post-EPA & $?$ & $\begin{array}{c}-0.437 \\
(-2.15)^{* *} \\
\end{array}$ & $\begin{array}{c}-0.586 \\
(-2.80)^{* * *} \\
\end{array}$ & $\begin{array}{l}-0.100 \\
(-0.37) \\
\end{array}$ & $\begin{array}{l}-0.268 \\
(-0.97) \\
\end{array}$ & $\begin{array}{c}-0.545 \\
(-2.22)^{* *} \\
\end{array}$ & $\begin{array}{l}-0.785 \\
(-3.16) \\
\end{array}$ \\
\hline Chdiv*Post-EPA & - & $\begin{array}{c}-3.047 \\
(-12.56)^{* * *} \\
\end{array}$ & $\begin{array}{c}-3.041 \\
(-14.59) * * * \\
\end{array}$ & $\begin{array}{c}-1.055 \\
(-2.68)^{* * *}\end{array}$ & $\begin{array}{c}-1.097 \\
(-3.33)^{* * *}\end{array}$ & $\begin{array}{c}-3.839 \\
(-10.09)^{* * *}\end{array}$ & $\begin{array}{c}-4.719 \\
(-15.21)^{* * *} \\
\end{array}$ \\
\hline Utility*Chdiv*Post-EPA & + & $\begin{array}{c}7.148 \\
(5.55)^{* * *} \\
\end{array}$ & $\begin{array}{c}7.605 \\
(5.57)^{* * *} \\
\end{array}$ & $\begin{array}{c}5.262 \\
(2.22)^{* *} \\
\end{array}$ & $\begin{array}{c}5.252 \\
(2.08)^{* *} \\
\end{array}$ & $\begin{array}{c}7.172 \\
(4.92)^{* * *} \\
\end{array}$ & $\begin{array}{c}8.432 \\
(5.52)^{* * *} \\
\end{array}$ \\
\hline Yield & + & $\begin{array}{c}40.029 \\
(17.36)^{* * *} \\
\end{array}$ & $\begin{array}{c}17.010 \\
(11.06)^{* * *} \\
\end{array}$ & $\begin{array}{c}37.051 \\
(15.87)^{* * *} \\
\end{array}$ & $\begin{array}{c}16.588 \\
(10.75)^{* * *} \\
\end{array}$ & $\begin{array}{c}55.675 \\
(18.63)^{* * *} \\
\end{array}$ & $\begin{array}{c}21.197 \\
(11.42)^{* * *} \\
\end{array}$ \\
\hline DNEG & $?$ & & & $\begin{array}{l}0.086 \\
(0.39) \\
\end{array}$ & $\begin{array}{c}0.387 \\
(1.99)^{* *} \\
\end{array}$ & & \\
\hline DNEG*Chdiv & $?$ & & & $\begin{array}{c}7.872 \\
(10.90)^{* * *}\end{array}$ & $\begin{array}{c}7.142 \\
(11.17)^{* * *}\end{array}$ & & \\
\hline DNEG*Post-EPA & $?$ & & & $\begin{array}{l}-0.406 \\
(-1.39)\end{array}$ & $\begin{array}{c}-0.515 \\
(-1.94)^{*}\end{array}$ & & \\
\hline DNEG*Utility & $?$ & & & $\begin{array}{r}-0.873 \\
(-1.57) \\
\end{array}$ & $\begin{array}{l}-0.906 \\
(-1.57) \\
\end{array}$ & & \\
\hline DNEG*Utility*Post-EPA & $?$ & & & $\begin{array}{l}1.317 \\
(1.11) \\
\end{array}$ & $\begin{array}{c}2.487 \\
(1.98)^{* *}\end{array}$ & & \\
\hline
\end{tabular}




\begin{tabular}{|c|c|c|c|c|c|c|c|}
\hline DNEG*Utility*Chdiv & $?$ & & & $\begin{array}{c}-9.018 \\
(-4.54)^{* * *} \\
\end{array}$ & $\begin{array}{c}-7.023 \\
(-3.38)^{* * *} \\
\end{array}$ & & \\
\hline DNEG*Chdiv*Post-EPA & $?$ & & & $\begin{array}{c}-5.975 \\
(-5.84)^{* * *} \\
\end{array}$ & $\begin{array}{c}-6.305 \\
(-6.83)^{* * *} \\
\end{array}$ & & \\
\hline $\begin{array}{l}\text { DNEG*Utility*Chdiv*Po } \\
\text { st-EPA }\end{array}$ & + & & & $\begin{array}{c}8.223 \\
(1.84)^{*}\end{array}$ & $\begin{array}{c}12.331 \\
(2.59)^{* * *}\end{array}$ & & \\
\hline DTOBIN & $?$ & & & & & $\begin{array}{c}0.896 \\
(11.27)^{* * *}\end{array}$ & $\begin{array}{c}0.566 \\
(8.07)^{* * *}\end{array}$ \\
\hline DTOBIN*Post-EPA & $?$ & & & & & $\begin{array}{c}-0.602 \\
(-4.68) * * *\end{array}$ & $\begin{array}{c}-0.423 \\
(-3.73)^{* * *}\end{array}$ \\
\hline DTOBIN*Utility & $?$ & & & & & $\begin{array}{c}-0.663 \\
(-2.89)^{* *} \\
\end{array}$ & $\begin{array}{l}-0.360 \\
(-1.55) \\
\end{array}$ \\
\hline DTOBIN*Chdiv & $?$ & & & & & $\begin{array}{c}-5.081 \\
(-14.49)^{* * * *} \\
\end{array}$ & $\begin{array}{c}-4.172 \\
(-13.47)^{* * *} \\
\end{array}$ \\
\hline $\begin{array}{l}\text { DTOBIN*Utility*Post-E } \\
\text { PA }\end{array}$ & $?$ & & & & & $\begin{array}{c}1.043 \\
(1.78)^{*} \\
\end{array}$ & $\begin{array}{c}1.256 \\
(2.15)^{* *} \\
\end{array}$ \\
\hline DTOBIN*Utility*Chdiv & $?$ & & & & & $\begin{array}{c}9.844 \\
(2.34)^{* *} \\
\end{array}$ & $\begin{array}{r}6.131 \\
-1.39 \\
\end{array}$ \\
\hline $\begin{array}{l}\text { DTOBIN*Chdiv*Post-E } \\
\text { PA }\end{array}$ & $?$ & & & & & $\begin{array}{c}4.452 \\
(7.25)^{* * *} \\
\end{array}$ & $\begin{array}{c}4.513 \\
(8.53)^{* * *} \\
\end{array}$ \\
\hline $\begin{array}{l}\text { DTOBIN*Utility*Chdiv* } \\
\text { Post-EPA }\end{array}$ & - & & & & & $\begin{array}{l}-0.844 \\
(-0.22)\end{array}$ & $\begin{array}{l}-0.711 \\
(-0.17)\end{array}$ \\
\hline $\mathrm{R}^{2}(\%)$ & & 7.26 & 5.04 & 8.08 & 5.48 & 8.49 & 5.75 \\
\hline No. of observations & & 35,592 & 55,427 & 35,592 & 55,427 & 28,075 & 43,494 \\
\hline F STAT. FOR $\quad \beta_{2}+\beta_{4}=0$ & & 1.07 & $5.42 * *$ & & & & \\
\hline F STAT. FOR $\quad \beta_{2}+\beta_{6}=0$ & & $332.52 * * *$ & $364.80 * * *$ & & & & \\
\hline F STAT. FOR $\beta_{2}+\beta_{4}+\beta_{6}+\beta_{7}=0$ & & $15.34 * * *$ & $21.03 * * *$ & & & & \\
\hline F STAT. FOR $\quad \beta_{5}+\beta_{12}=0$ & & & & 0.38 & 0.00 & & \\
\hline F STAT. FOR $\beta_{5}+\beta_{13}=0$ & & & & $6.78 * * *$ & 1.58 & & \\
\hline F STAT. FOR $\beta_{5}+\beta_{12}+\beta_{13}+\beta_{15}=0$ & & & & 0.08 & 2.11 & & \\
\hline F STAT. FOR $\quad \beta_{5}+\beta_{12}=0$ & & & & & & 1.32 & 0.2 \\
\hline F STAT. FOR $\beta_{5}+\beta_{13}=0$ & & & & & & 1.56 & 0.63 \\
\hline F STAT. FOR $\beta_{5}+\beta_{12}+\beta_{13}+\beta_{15}=0$ & & & & & & $3.40^{*}$ & 1.43 \\
\hline
\end{tabular}

\section{Notes to Table 4}

Returns are expressed as percentages.

Variables are defined as below:

CAR Compounded abnormal return (either beta or market adjusted and expressed as a percentage) over the two-day dividend announcement window.

Utility Indicator variable that takes the value one when the observation pertains to an electric utility and zero otherwise.

Post-EPA Indicator variable that takes the value one when the observation pertains to years after 1991 and zero otherwise.

Chdiv Change in dividends computed as dividend minus previous dividend scaled by previous dividend.

DNEG Indicator variable that takes the value 1 if CHDIV is less than zero and 0 otherwise.

Yield Dividend yield computed as the ratio of the annual dividend to stock price.

DTOBIN Indicator variable that takes the value 1 if the firm's Tobin's $Q$ is higher than the median in that year.

$* * *$ Significant at the $1 \%$ level $\quad * *$ Significant at the $5 \%$ level $\quad *$ Significant at the $10 \%$ level 
To summarize our investigation of the stock market reaction to electric utility dividend changes, there is little evidence that the market reacted systematically to changes in electric utility dividends in the period when regulation was in effect in the industry. In the period when deregulation has been initiated, the market is beginning to react to changes in utility dividends the same way it reacts to the dividend changes of unregulated firms. Dividend increases are generally interpreted as good news and decreases as bad news. In the next section, we examine the pattern of future earnings following dividend changes for electric utilities to see if we can discern patterns consistent with the use of dividends to signal future firm performance.

\subsection{Earnings Changes Surrounding Dividend Changes: Empirical Results}

Table 5 presents the results of estimating equation (5). We report the results separately for cases when the dependent variable is the one year change in IBEI, the two year change in IBEI and the three year change in IBEI. If non-electric utilities used changes in dividends to signal their future prospects in the earlier period, we would expect a positive and significant coefficient on CHDIV. The results are not consistent with this implication. The coefficient on CHDIV is negative and significant when the dependent variable is change in one year out earnings and insignificant for the other two horizons. If these firms used dividend changes in the later period to signal changed earnings prospects, we would expect the sum of the coefficients on CHDIV and POST-EPA*CHDIV to be positive and significantly different from zero. The results of the F-test are consistent with this prediction when the dependent variable is two and three year out changes in earnings. There is therefore some support for the signaling theory for non-electric utilities in the later time period.

Table 5. Multivariate analysis of relation between dividend changes and changes in future earnings

\begin{tabular}{|c|c|c|c|}
\hline Variable & & Dependent Variable & \\
\hline & $\begin{array}{c}\text { One year \% change in } \\
\text { IBEI }\end{array}$ & $\begin{array}{c}\text { Two year } \% \text { change in } \\
\text { IBEI }\end{array}$ & $\begin{array}{c}\text { Three year } \% \text { change in } \\
\text { IBEI }\end{array}$ \\
\hline Intercept & $\begin{array}{c}1.540 \\
(7.14)^{* * *} \\
\end{array}$ & $\begin{array}{c}1.660 \\
(4.91)^{* * *} \\
\end{array}$ & $\begin{array}{c}3.184 \\
(8.03)^{* * *} \\
\end{array}$ \\
\hline Utility & $\begin{array}{l}-0.467 \\
(-0.50) \\
\end{array}$ & $\begin{array}{l}0.950 \\
(0.66) \\
\end{array}$ & $\begin{array}{l}0.983 \\
(0.59) \\
\end{array}$ \\
\hline Post-EPA & $\begin{array}{c}-4.389 \\
(-12.29)^{* * *} \\
\end{array}$ & $\begin{array}{c}-10.987 \\
(-18.95)^{* * *}\end{array}$ & $\begin{array}{c}-14.030 \\
(-19.79)^{* * *}\end{array}$ \\
\hline Chdiv & $\begin{array}{c}-2.161 \\
(-5.46)^{* * *}\end{array}$ & $\begin{array}{l}0.582 \\
(0.93) \\
\end{array}$ & $\begin{array}{l}-0.149 \\
(-0.20) \\
\end{array}$ \\
\hline Utility*Post-EPA & $\begin{array}{c}4.159 \\
(2.22)^{* *} \\
\end{array}$ & $\begin{array}{c}8.807 \\
(2.91)^{* * *}\end{array}$ & $\begin{array}{c}9.913 \\
(2.69)^{* * *}\end{array}$ \\
\hline Utility*Chdiv & $\begin{array}{l}5.329 \\
(1.05) \\
\end{array}$ & $\begin{array}{l}0.242 \\
(0.03) \\
\end{array}$ & $\begin{array}{l}0.822 \\
(0.09) \\
\end{array}$ \\
\hline Post-EPA*Chdiv & $\begin{array}{c}1.772 \\
(2.92)^{* * *}\end{array}$ & $\begin{array}{c}2.117 \\
(2.13)^{* *}\end{array}$ & $\begin{array}{c}2.931 \\
(2.41)^{* *}\end{array}$ \\
\hline Utility*Post-EPA*Chdiv & $\begin{array}{l}-8.077 \\
(-1.22) \\
\end{array}$ & $\begin{array}{l}-0.441 \\
(-0.04) \\
\end{array}$ & $\begin{array}{l}-8.507 \\
(-0.67) \\
\end{array}$ \\
\hline $\mathrm{R}^{2}(\%)$ & 0.18 & 0.43 & 0.49 \\
\hline No. of observations & 98,042 & 90,637 & 83,442 \\
\hline $\mathrm{F}$ for $\beta_{3}+\beta_{6}=0$ & 0.72 & $12.34 * * *$ & $8.35 * * *$ \\
\hline $\mathrm{F}$ for $\beta_{3}+\beta_{5}=0$ & 0.39 & 0.01 & 0.01 \\
\hline $\mathrm{F}$ for $\beta_{3}+\beta_{5}+\beta_{6}+\beta_{7}=0$ & 0.54 & 0.12 & 0.32 \\
\hline
\end{tabular}

t-statistics are in parentheses below the coefficients. Significant at the $1 \%$ level $* *$ Significant at the $5 \%$ level

* Significant at the $10 \%$ level

\section{Variable Definitions:}

IBEI Income before extraordinary items scaled by book value of common equity.

Utility Indicator variable that takes the value one when the observation pertains to an electric utility and zero otherwise. 
Post-EPA Indicator variable that takes the value one when the observation pertains to years after 1991 and zero otherwise.

Chdiv Change in dividends computed as dividend minus previous dividend scaled by previous dividend.

If utilities used dividends to signal future earnings in the regulated regime, we would expect the sum of the coefficients on CHDIV and UTILITY*CHDIV to be significantly different from zero. F-tests do not support this hypothesis. Similarly if electric utilities used dividend changes to signal future earnings in the deregulated period, we expect that the sum of the coefficients on CHDIV, UTILITY*CHDIV, POST-EPA*CHDIV and UTILITY*POST-EPA*CHDIV to be significantly different from zero. Again F-tests show that this sum is not statistically distinguishable from zero. The tests in this sub-section therefore do not support the idea that utilities are more likely to signal future earnings using dividends after the onset of deregulation. In addition, the $\mathrm{R}^{2}$ of the regressions are small, less than $1 \%$, suggesting that, if there is signaling, the signals are noisy.

\section{Discussion}

Utilities, in the regulated regime, were characterized by high dividend payouts and stability in dividends. With the onset of deregulation in the electric utility industry, firms in this industry faced competitive pressures for the first time. Therefore, it is possible that electric utilities might change their dividend policies to more closely resemble their counterparts in other industries. If clientele effects are strong, however, electric utilities might maintain their high dividend payouts in spite of the changed environment. Overall, we find that electric utilities largely maintained their levels of dividends even as their profitability declined and we interpret this result as being consistent with the dividend clientele theory for dividends.

We also investigate stock market responses to announcements of changes in utility dividends, both in the regulated regime and after the onset of deregulation. We find little evidence that the stock market reacts to utility dividend changes in the earlier period. In the latter period, the stock market reaction to electric utility dividend changes more closely resembles that of non-utility firms. We find weak evidence that the magnitude of the response for electric utilities in the deregulated period is related to firms' investment opportunity sets. The free cash flow theory for dividends would suggest such a relationship. Lastly, we examine earnings changes surrounding dividend changes for utilities. We do not find indications that changes in dividends are used to signal future earnings for electric utilities. Overall, we interpret our results as being consistent with theory of dividend clienteles. Electric utilities appear to attempt to retain their high dividend clientele even as they face greater competition and have access to greater investment opportunities. Our results are not consistent with Smith (1986)'s theory that dividends might be used in regulated industries to resolve agency conflicts with regulators. Some of our results are consistent with Jensen (1986)'s free cash flow theory as it relates to dividends. However, we find very little support for the dividend signaling theory. Changes in dividends for electric utilities do not appear to signal future firm performance in the deregulated regime as this theory would predict.

\section{References}

Agrawal, A., \& Jayaraman, N. (1994). The dividend policies of all-equity firms: A direct test of the free cash flow theory. Managerial and Decision Economics, 15(2), 139-148. http://dx.doi.org/10.1002/mde.4090150206

Allen, F., Bernardo, A., \& Welch, I. (2000). A theory of dividends based on tax clientele. Journal of Finance, 55(6), 2499-2536. http://dx.doi.org/10.1111/0022-1082.00298

Bajaj, M., \& Vijh, A. (1990). Dividend clienteles and the information content of dividend changes. Journal of Financial Economics, 26, 193-219. http://dx.doi.org/10.1016/0304-405X(90)90003-I

Bhattacharya, S. (1979). Imperfect information, dividend policy, and 'the bird-in-the-hand' fallacy. Bell Journal of Economics, 10, 259-270. Retrieved from http://www.jstor.org/stable/3003330

Benartzi, S., Michaely, R., \& Thaler, R. (1997). Do changes in dividends signal the future or the past? Journal of Finance, 52(July), 1007-1034. http://dx.doi.org/10.1111/j.1540-6261.1997.tb02723.x

Brav, A., Graham, J. R., Harvey, C. R., \& Michaely, R. (2005). Payout policy in the $21^{\text {st }}$ century. Journal of Financial Economics, 77(3), 483-527. http://dx.doi.org/10.1016/j.jfineco.2004.07.004

DeAngelo, H., DeAngelo, L., \& Skinner, D. (1996). Reversal of fortune: Dividend signaling and the disappearance of sustained earnings growth. Journal of Financial Economics, 40(3), 341-371. http://dx.doi.org/10.1016/0304-405X(95)00850-E 
Elton, E., \& Gruber, M. (1970). Marginal stockholder tax rates and the clientele effect. Review of Economics \& Statistics, 52(1), 68-74. http://dx.doi.org/10.2307/1927599

Erickson, T., \& Whited, T. M. (2006). On the accuracy of different measures of Q. Financial Management, 35, 5-33. http://dx.doi.org/10.1111/j.1755-053X.2006.tb00145.x

Fama, E., \& French, K. (2001). Disappearing dividends: Changing firm characteristics or lower propensity to pay? Journal of Financial Economics, 60(1), 3-43. http://dx.doi.org/10.1016/S0304-405X(01)00038-1

Fama, E., \& French, K. (2002). Testing tradeoff and pecking order predictions about dividends and debt. Review of Financial Studies, 15(Spring), 1-37.

Graham, J. R., \& Kumar, A. (2006). Do dividend clienteles exist? Evidence on dividend preferences of retail investors. Journal of Finance, 61(3), 1305-1336. http://dx.doi.org/10.1111/j.1540-6261.2006.00873.x

Grullon, G., Michaely, R., Benartzi, S., \& Thaler, R. H. (2005). Dividend changes do not signal changes in future profitability. Journal of Business, 78, 1659-1682.

Hansen, R., Kumar, R., \& Shome, D. (1994). Dividend policy and corporate monitoring: Evidence from the regulated electric utility industry. Financial Management, (Spring), 16-22. Retrieved from http://www.jstor.org/stable/3666052

Healy, P., \& Palepu, K. (1988). Earnings information conveyed by dividend initiations and omissions. Journal of Financial Economics, 21, 149-175. http://dx.doi.org/10.1016/0304-405X(88)90059-1

Jensen, G., Solberg, D., \& Zorn, T. (1992). Simultaneous determination of insider ownership, debt and dividend policies. Journal of Financial and Quantitative Analysis, 27, 247-263. Retrieved from http://www.jstor.org/stable/2331370

Jensen, M. (1986). Agency costs of free cash flow, corporate finance, and takeovers. American Economic Review, 76, 323-329.

John, K., \& Lang, L. (1991). Strategic insider trading around dividend announcements: Theory and evidence. Working paper, New York University.

John, K., \& Williams, J. (1985). Dividends, dilution, and taxes: A signaling equilibrium. Journal of Finance, 40, 1053-1070. Retrieved from http://www.jstor.org/stable/2328394

Johnson, M. S., Niles, M. S., \& Suydam, S. L. (1998). Regulatory changes in the electric utility industry: Investigation of effects on shareholder wealth. Journal of Accounting and Public Policy, 17, 285-309. http://dx.doi.org/10.1016/S0278-4254(98)10013-3

Lang, L., \& Litzenberger, R. (1989). Dividend announcements, cash flow signaling vs. free cash flow hypothesis. Journal of Financial Economics, 24, 181-191. http://dx.doi.org/10.1016/0304-405X(89)90077-9

Lease, R., John, K., Kalay, A., Loewenstein, U., \& Sarig, O. (1999). Dividend policy: Its impact on firm value.

Lintner, J. (1956). Distribution of incomes of corporations among dividends, retained earnings, and taxes. American Economic Review, 46, 97-113. Retrieved from http://www.jstor.org/stable/1910664

Miller, M. H., \& Modigliani, F. (1961). Dividend policy, growth and the valuation of shares. Journal of Business, 34, 411-433. Retrieved from http://www.jstor.org/stable/2351143

Miller, M., \& Rock, K. (1985). Dividend policy under asymmetric information. Journal of Finance, 40, 1031-1051. http://dx.doi.org/10.1111/j.1540-6261.1985.tb02362.x

Nissim, D., \& Ziv, A. (2001). Dividend changes and future profitability. Journal of Finance, 61, 2111-2133.

Smith, C. (1986). Investment banking and the capital acquisition process. Journal of Financial Economics, 15, 3-30. http://dx.doi.org/10.1016/0304-405X(86)90048-6

Smith, C., \& Watts, R. (1992). The investment opportunity set and corporate financing, dividend, and compensation policies. Journal of Financial Economics, 32, 263-292. http://dx.doi.org/10.1016/0304-405X(92)90029-W

Watts, R. (1973). The information content of dividends. Journal of Business, 46, 191-211. Retrieved from http://www.jstor.org/stable/2351363

Yoon, P., \& Starks, L. (1995). Signaling, investment opportunities, and dividend announcements. The Review of Financial Studies, 8(Winter), 995-1018. Retrieved from http://www.jstor.org/stable/2962297 


\section{Notes}

Note 1. Lease et al. (1999) provide a comprehensive survey of this literature. Miller and Modigliani (1961) showed that in a world with perfect capital markets, dividend policy is irrelevant.

Note 2. We choose to treat 1992, the year of the enactment of the Energy Policy Act, as demarcating the regulated from the deregulated regimes. To the extent that the transition between regimes was more gradual, noise would be introduced into the analysis. We believe that this noise would bias our tests towards the null of no difference between regimes.

Note 3. We use this measure of Tobin's Q because Erickson and Whited (2006) find that it captures firms' incentive to invest almost as well as measures which use more elaborate algorithms. They also note that data to compute this measure is available for more firms which reduces the probability of a selection bias.

Note 4. Although we are primarily interested in the coefficient on DNEG*POST*UTILITY*CHDIV, we include DNEG, POST, UTILITY and CHDIV by themselves and their various interactions to avoid ascribing effects to this interaction which are due to the main effects or other interactions.

Note 5. See the literature review for a summary of this research.

Note 6. In untabulated results, we also perform a firm fixed effects estimation to control for firm specific factors that affect dividends per-share. The results are not significantly different from the OLS and GEE estimations.

Note 7. This latter result is also consistent with the pecking-order theory of corporate finance which predicts that firms prefer internal finance for investments and adapt their payout ratios to their investment opportunities while avoiding abrupt changes in dividends. 